\title{
The potential of Spent Substrate of Oyster (Pleurotus ostreatus) dan Shiitake (Lentinula edodes) Mushrooms to Control Damping-off Disease (Rhizoctonia solani) in Tomato
}

\author{
Lia Herawati ${ }^{1}$, Noor Istifadah ${ }^{2 *}$, \\ ${ }^{1}$ Alumnus of Departement of Plant Pests and Diseases, Agriculture Faculty, Universitas Padjadjaran, Jatinangor, West \\ Java, Indonesia, 45363. \\ ${ }^{2}$ Departement of Plant Pests and Diseases, Agriculture Faculty, Universitas Padjadjaran, Jatinangor, West Java, \\ Indonesia, 45363. \\ * Corresponding author : n.istifadah@unpad.ac.id
}

\begin{abstract}
Spent mushroom substrates are potential for controlling plant diseases. This study examined the abilities of spent substrates of Shiitake (L. edodes) and Oyster (P. ostreatus) mushrooms to inhibit the growth of $R$. solani in vitro and control dampingoff disease in tomato seedling. The in vitro experiment examined the abilities of water extract of spent mushroom substrate non-sterile and sterile to inhibit the pathogen using poisonous food method. In the nursery experiment, substrates were mixed with the planting medium, 1:1, 1:2, and 1:3 (v/v). The result showed that the water extract of spent substrates of $L$. edodes and P. ostreatus inhibited the growth of $R$. solani by $29.1 \%-40.6 \%$. Non sterile water extract of spent substrate of $P$. osteratus showed highest inhibition level (40\%). In tomato nursery, mixing spent substrates of L. edodes or P. ostreatus with planting medium 1:2, and 1:3 (v/v) inhibited damping-off disease in tomato seedling by $57.5 \%-100 \%$. Application of P. ostreatus spent substrate in the planting medium, 1:2 and 1:3 (v/v) resulted in $100 \%$ inhibition of the disease.
\end{abstract}

Key words: tomato seedlings, water extract, spent mushroom substrate, in vitro

\section{ABSTRAK \\ Potensi Limbah Media Jamur Tiram (Pleurotus ostreatus) dan Shiitake (Lentinula edodes) untuk Mengendalikan Penyakit Rebah Semai (Rhizoctonia solani) pada Tomat}

Limbah media jamur konsumsi dapat dimanfaatkan sebagai alternatif untuk mengendalikan penyakit tanaman. Penelitian ini bertujuan untuk menguji kemampuan limbah media jamur Tiram (P. osteratus) dan jamur Shiitake (L. edodes) untuk menghambat pertumbuhan $R$. solani in vitro dan mengendalikan penyakit rebah semai pada pembibitan tomat. Pada percobaan in vitro yang diuji adalah ekstrak air limbah media tanam jamur yang non steril dan steril. Pada uji in vivo, limbah diaplikasikan dengan cara dicampur dengan medium tanam dengan perbandingan 1:1, 1:2, dan 1:3 (v/v). Hasil percobaan secara in vitro menunjukkan bahwa limbah jamur Tiram dan Shiitake dapat menghambat pertumbuhan miselium $R$. solani sebesar $29,1 \%$ - 40,6\%. Ekstrak air limbah media tanam jamur Tiram yang non steril menghasilkan persentase penghambatan tertinggi yaitu 40\%. Aplikasi limbah media tanam jamur Tiram dan Shiitake dapat menekan perkembangan penyakit rebah semai pada pembibitan tomat sebesar 57,5\% - 100\%. Persentase penghambatan sebesar $100 \%$ terdapat pada perlakuan aplikasi limbah jamur Tiram dengan perbandingan 1:2 dan 1:3 (v/v).

Kata kunci : bibit tomat, ekstrak air, jamur konsumsi, in vitro

\section{PENDAHULUAN}

Penyakit rebah semai yang disebabkan oleh Rhizoctonia solani Kuhn merupakan salah satu kendala dalam pembibitan tanaman tomat. Penyakit ini dapat menyebabkan benih membusuk dalam tanah, kecambah mati sebelum muncul ke permukaan tanah, atau bibit tanaman rebah dan mati karena pangkal batangnya terinfeksi. Jaringan yang terinfeksi berwarna cokelat kemerahan, lunak dan mengerut. Jamur patogen ini sulit dikendalikan karena dapat membentuk sklerosia yang bertahan lama dalam tanah (Semangun, 2004; Agrios, 2005).

Sampai saat ini petani belum melakukan pengendalian penyakit rebah semai secara khusus. Penggunaan jenis bahan organik tertentu dapat menekan penyakit tular tanah (Bonanomi et al., 2007). Namun, bahan organik yang biasa digunakan petani yaitu pupuk kandang domba atau ayam masih belum efektif menekan penyakit tersebut. Bahan organik yang berpotensi untuk pengendalian penyakit tanaman adalah adalah limbah media jamur konsumsi atau spent mushroom substrate (SMS) (Suess \& Curtis, 2006; Ahlawat \& Sagar, 2007).

Limbah media tanam jamur konsumsi ini banyak mengandung nutrisi yang diperlukan oleh tanaman sehingga berpotensi digunakan sebagai pupuk. Selain itu, limbah media jamur konsumsi juga berpotensi untuk mengendalikan penyakit tanaman (Suess \& Curtis, 2006). Limbah media jamur kancing (Agaricus bisporus) dilaporkan dapat menekan penyakit rebah semai pada seledri yang disebabkan oleh Phytophthora drechsleri (Goonani et al., 2011). Kompos bekas media jamur Tiram P. ostreatus dan P. sajor-caju dapat menekan jumlah sista Heterodera schachtii pada tanaman gula bit (Palizi et al., 2009). Limbah media jamur Hericium erinaceus dapat menekan penyakit layu bakteri yang disebabkan oleh Ralstonia solanacearum pada tanaman tomat (Kwak et al., 2015). 
Kemampuan limbah media tanam jamur konsumsi untuk menekan penyakit dapat dikarenakan beberapa hal. Limbah media jamur mengandung mikrob yang berpotensi sebagai antagonis patogen tanaman (Suess \& Curtis, 2006; Ahlawat \& Sagar, 2007; Adedeji \& Modupe, 2016). Limbah jamur konsumsi juga dapat mengandung senyawa yang dapat menghambat patogen (Kwak et al., 2015) dan menginduksi resistensi tanaman (Parada et al., 2011).

Jamur yang dibudidayakan di daerah dataran tinggi di Jawa Barat antara lain Tiram (Pleurotus sp.) dan jamur Shiitake (Lentinus edodes). Dalam artikel ini, dibahas hasil penelitian yang mengkaji kemampuan dan dosis aplikasi media limbah tanam jamur Tiram (Pleurotus sp.) dan jamur Shiitake (Lentinus edodes) untuk menekan penyakit rebah semai (R. solani) pada tomat.

\section{BAHAN DAN METODE}

Percobaan dilakukan secara in vitro dan in vivo. Percobaan secara in vivo pada bibit tomat ditujukan untuk menguji kemampuan limbah untuk menekan penyakit rebah semai, sedangkan percobaan in vitro lebih ditujukan untuk mengevaluasi apakah penekanan terhadap patogen karena efek mikrob yang ada dalam limbah dan atau/ karena senyawa kimianya.

\section{Percobaan in Vitro}

Percobaan secara in vitro dilakukan dengan Rancangan Acak Lengkap (RAL) yang terdiri atas lima perlakuan dengan empat ulangan. Perlakuan yang diuji adalah:

A. Limbah media tanam jamur Shiitake steril

B. Limbah media tanam jamur Tiram steril

C. Limbah media tanam jamur Shiitake non steril

D. Limbah media tanam jamur Tiram non steril

E. Kontrol

Limbah media tanam jamur Tiram dan Shiitake diperoleh dari Perusahaan Inti Jamur Raya,

Lembang, Bandung Barat. Limbah telah dibiarkan sekitar tiga bulan sehingga $\mathrm{C} / \mathrm{N}$ rasionya untuk limbah jamur Tiram adalah 16,6 sedangkan $\mathrm{C} / \mathrm{N}$ rasio limbah jamur Shiitake adalah 17,4. Limbah media jamur tersebut dicampur dengan air steril dengan perbandingan 1:4 (v/v), kemudian dihomogenkan dengan stirrer selama 5 menit. Ekstrak air kemudian diendapkan dan disaring dengan kertas saring. Untuk perlakuan steril, ekstrak air tersebut disterilisasi dengan menggunakan microfilter (ukuran pori 0,4 $\mu \mathrm{m}$ dan $0,2 \mu \mathrm{m})$. Pengujian dilakukan dengan metode poisoneous food (Dhingra \& Sinclair, 1995) yaitu dengan cara ekstrak air limbah jamur non steril dan yang telah disterilkan dimasukkan ke dalam cawan petri sebanyak $1 \mathrm{ml}$, kemudian ditambahkan Potato Dextrose Agar hangat sebanyak $9 \mathrm{ml}$. Setelah media padat, potongan biakan jamur patogen $R$. solani diletakkan pada bagian tengah media.

Pengamatan dilakukan setiap hari dengan mengukur jari-jari koloni patogen. Data yang diperoleh digunakan untuk perhitungan Area Under
Colony Growth Curve (ACGC) yang menggambarkan total pertumbuhan jamur selama pengamatan (Istifadah \& McGee, 2006). Rumus AUCGC dimodifikasi dari rumus Area Under Disease Development Curve atau AUDPC (Campbell \& Madden, 1990) yaitu :

AUDPC $=\sum_{i}^{n-1}\left\{\left(\frac{Y_{i}+Y_{i+1}}{2}\right)\right\}\left(\mathrm{t}_{i+1}+\mathrm{t}_{i}\right)$

Untuk rumus AUCGC,

$\mathrm{Y}_{\mathrm{i}} \quad=$ jari-jari koloni pada saat $\mathrm{i}$,

$\mathrm{Y}_{\mathrm{i}+1}=$ jari-jari koloni pada saat $\mathrm{i}+1$ dan

$\mathrm{t} \quad=$ interval waktu antar pengamatan

(Istifadah \& McGee, 2006).

\section{Percobaan in Vivo}

Percobaan secara in vivo dilakukan dengan menggunakan Rancangan Acak Kelompok (RAK). Percobaan terdiri dari 7 perlakuan dengan 3 ulangan dan setiap ulangan terdiri dari 15 tanaman. Perlakuan yang diuji adalah sebagai berikut:

A. Aplikasi limbah media jamur Shiitake pada media persemaian $1: 1(\mathrm{v} / \mathrm{v})$

B. Aplikasi limbah media jamur Shiitake pada media persemaian $1: 2(\mathrm{v} / \mathrm{v})$

C. Aplikasi limbah media jamur Shiitake pada media persemaian 1:3(v/v)

D. Aplikasi limbah media jamur Tiram pada media persemaian $1: 1(\mathrm{v} / \mathrm{v})$

E. Aplikasi limbah media jamur Tiram pada media persemaian 1:2(v/v)

F. Aplikasi limbah media jamur Tiram pada media persemaian 1:3(v/v)

G. Kontrol.

Isolat jamur patogen $R$. solani dibiakkan pada media beras dengan cara yaitu beras direndam semalam, kemudian dimasukkan ke dalam plastik tahan panas sebanyak $100 \mathrm{~g}$ dan disterilisasi menggunakan autoclave $\left(121{ }^{\circ} \mathrm{C}, 1 \mathrm{~atm}\right)$ selama 15 menit. Sebanyak 3 potongan biakan $R$. solani (diameter $0,8 \mathrm{~cm}$ ) diinokulasikan ke dalam media steril yang telah dingin kemudian diinkubasikan selama 2 minggu.

Guna penyemaian benih tomat, medium yang digunakan adalah medium yang biasa digunakan petani yaitu tanah yang dicampur pupuk kandang kambing (3: 1, v/v) serta sekam bakar 5\%. Sebelum digunakan medium tersebut dikukus dulu selama 4 jam. Benih tomat kemudian disemaikan pada medium tersebut dan bibit yang berumur 7 hari digunakan untuk percobaan.

Medium tanam yang digunakan untuk percobaan adalah tanah yang telah dikukus selama 4 jam dan dicampur sekam bakar $(5 \%$, v/v). Sebelum digunakan, limbah jamur yang berupa bongkahan medium tanam dihaluskan. Limbah medium jamur tersebut kemudian dicampur dengan medium tanam dengan perbandingan sesuai perlakuan, kecuali pada kontrol. Medium tanam kemudian dimasukkan ke 
dalam wadah plastik berukuran $25 \times 20 \times 5 \mathrm{~cm}$ kemudian dibuat 15 lubang tanam. Pada masingmasing lubang tanam dinokulasikan biakan $R$. solani sebanyak $0,5 \mathrm{~g}$ per lubang tanam. Setelah itu, semai tomat yang berumur 7 hari ditanam pada lubang tanam tersebut.

Pengamatan dilakukan dengan menghitung persentase tanaman yang terinfeksi. Pengamatan dilakukan setiap hari setelah inokulasi patogen sampai pada kontrol tidak ada lagi penambahan semai yang terinfeksi. Data yang diperoleh digunakan untuk menghitung AUDPC.

\section{HASIL DAN PEMBAHASAN}

\section{Pengujian secara in Vitro}

Hasil pengujian yang dilakukan secara in vitro menunjukkan bahwa ekstrak air limbah media tanam jamur yang non steril dan ekstrak air limbah yang telah disterilkan dapat menghambat pertumbuhan miselium $R$. solani sebesar 29,1-46,7 \% (Tabel 1). Tujuan dilakukannya sterilisasi tersebut adalah untuk mengevaluasi apakah penghambatan patogen karena adanya senyawa yang bersifat toksik. Untuk limbah jamur Shiitake, penghambatan patogen pada perlakuan ekstrak air non steril dan steril ternyata tidak berbeda secara nyata. Hal ini mengindikasikan bahwa limbah media Shiitake mengandung mikrob dan senyawa toksik yang dapat menghambat pertumbuhan $R$. solani. Pada penelitian lain, ekstrak air limbah jamur Shiitake yang telah disterilkan juga dapat menghambat pertumbuhan Ralstonia solanacearum (Istifadah \& Sianipar, 2015; Kwak et al. 2015).

Pada perlakuan dengan limbah jamur Tiram, ekstrak air limbah jamur yang non steril menunjukkan penghambatan pertumbuhan miselium $R$. solani yang lebih baik dibandingkan dengan ekstrak yang steril. Hal ini berarti penghambatan patogen oleh limbah jamur Tiram lebih dikarenakan adanya mikrob yang bersifat antagonistik terhadap patogen. Pada penelitian Istifadah \& Sianipar (2015) air rendaman limbah jamur Tiram steril bahkan tidak menghambat pertumbuhan $R$. solanacearum secara in vitro.

Persentase penghambatan terhadap pertumbuhan $R$. solani yang paling tinggi terdapat pada perlakuan ekstrak air limbah media tanam jamur Tiram yang non steril (Tabel 1). Hal ini diduga karena limbah jamur Tiram tersebut mengandung lebih banyak mikrob yang bersifat antagonistik terhadap patogen. Ahlawat \& Sagar (2007) juga melaporkan bahwa limbah jamur Tiram mengandung lebih banyak mikrob dibandingkan limbah jamur merang (Volvariella volvaceae). Adedeji \& Modupe (2016) melaporkan bahwa ekstrak air limbah jamur Tiram mengandung mikrob antagonis antara lain Pseudomonas fluorescens, Trichoderma viridae, Bacillus spp., Penicillum spp., dan Aspergillus terrus.

Tabel 1. Efek Ekstrak Air Limbah Media Jamur Shiitake dan Tiram terhadap Pertumbuhan Jamur R. solani secara in Vitro

\begin{tabular}{lcc}
\hline \multicolumn{1}{c}{ Perlakuan } & Nilai AUCGC & $\begin{array}{c}\text { Persentase Penghambatan } \\
(\%)\end{array}$ \\
\hline Limbah media jamur Shiitake steril & $19,42 \mathrm{~b}$ & 29,1 \\
Limbah media jamur Tiram steril & $17,95 \mathrm{~b}$ & 31,2 \\
Limbah media jamur Shiitake non steril & $18,09 \mathrm{~b}$ & 33,4 \\
Limbah media jamur Tiram non steril & $16,24 \mathrm{a}$ & 40,7 \\
Kontrol & $27,15 \mathrm{c}$ & 0,0 \\
\hline
\end{tabular}

Keterangan : Nilai rata-rata dalam kolom yang diikuti dengan huruf yang sama tidak berbeda nyata menurut Uji Berganda Duncan pada taraf 5\%.

\section{Pengujian secara in Vivo}

Aplikasi limbah media tanam jamur di persemaian tomat dapat menekan persentase tanaman yang terinfeksi penyakit rebah semai sebesar 57,5\% $100 \%$ (Tabel 2). Hal ini sejalan dengan penelitian sebelumnya yang juga melaporkan kemampuan limbah jamur Shiitake dan jamur Tiram untuk menekan penyakit. Misalnya Istifadah \& Sianipar (2015) yang melaporkan bahwa aplikasi limbah media jamur Shiitake pada lubang tanam dan penyiraman air rendamannya setiap minggu dapat menghambat perkembangan penyakit layu bakteri pada kentang. Yusidah \& Istifadah (2018) juga melaporkan bahwa aplikasi limbah jamur Shiitake dan jamur Tiram pada lubang tanam dan penyiraman air rendamannya dua minggu sekali juga dapat menekan penyakit busuk pangkal bawang merah yang disebakan oleh jamur Fusarium oxysporum f.sp. cepae sebesar 68,7-70,5\%. Aplikasi limbah media tanam jamur tiram dengan perbandingan 1:2 dan 1:3 (v/v) dapat menekan penyakit rebah semai sebesar $100 \%$. Pada kedua perlakuan itu, tidak ada tanaman tomat yang terinfeksi penyakit rebah semai. Tanaman tomat yang diberi perlakuan tersebut pertumbuhannya lebih cepat dibandingkan dengan perlakuan yang lain dan juga kontrol (Gambar 1). Pada penelitian lain, limbah media tanam jamur tiram dan Shiitake juga dapat meningkatkan pertumbuhan bawang merah (Yusidah \& Istifadah, 2018) dan tanaman cabai (Roy et al., 2015). Mengingat bahwa dosis aplikasi limbah ke 
medium tanam 1:2 dan 1:3 (v/v) efeknya tidak berbeda nyata, maka guna efisiensi limbah jamur dapat diaplikasikan dengan dosis yang lebih rendah yaitu $1: 3(\mathrm{v} / \mathrm{v})$.

Hasil penelitian ini mengkonfirmasi bahwa limbah media tanam jamur Tiram dan Shiitake dapat dimanfaatkan sebagai salah satu upaya pengendalian penyakit terutama sebagai upaya preventif. Bahan organik ini juga dapat dimanfaatkan gunakan sebagai pupuk (Suess \& Curtis, 2006; Roy et al., 2015). Namun seperti bahan organik pada umumnya, penggunaan limbah media tanam jamur konsumsi ini juga harus memperhatikan $\mathrm{C} / \mathrm{N}$ rasio yang berdasarkan Permentan no. 70 tahun 2011 untuk pupuk organik padat yaitu antara $15-25$.

Tabel 2. Efek Limbah Media Jamur Shiitake dan Tiram terhadap Penyakit Rebah Semai pada Tomat

\begin{tabular}{llc}
\hline \multicolumn{1}{c}{ Perlakuan } & Nilai AUDPC & $\begin{array}{c}\text { Persentase Penghambatan } \\
(\%)\end{array}$ \\
\hline Limbah media jamur Shiitake 1:1 (v/v) & $25,50 \mathrm{~b}$ & 57,5 \\
Limbah media jamur Shiitake 1:2(v/v) & $7,77 \quad \mathrm{ab}$ & 87,1 \\
Limbah media jamur Shiitake 1:3(v/v) & $9,53 \mathrm{ab}$ & 84,1 \\
Limbah media jamur Tiram 1:1 (v/v) & $14,43 \mathrm{ab}$ & 75,9 \\
Limbah media jamur Tiram 1:2(v/v) & $0,00 \mathrm{a}$ & 100,0 \\
Limbah media jamur Tiram 1:3 (v/v) & $0,00 \mathrm{a}$ & 100,0 \\
Kontrol & $60,00 \mathrm{c}$ & 0,0 \\
\hline
\end{tabular}

Keterangan : Huruf yang sama pada satu kolom dalam tabel menunjukkan data tidak berbeda nyata berdasarkan Uji Jarak Berganda Duncan 5\%.
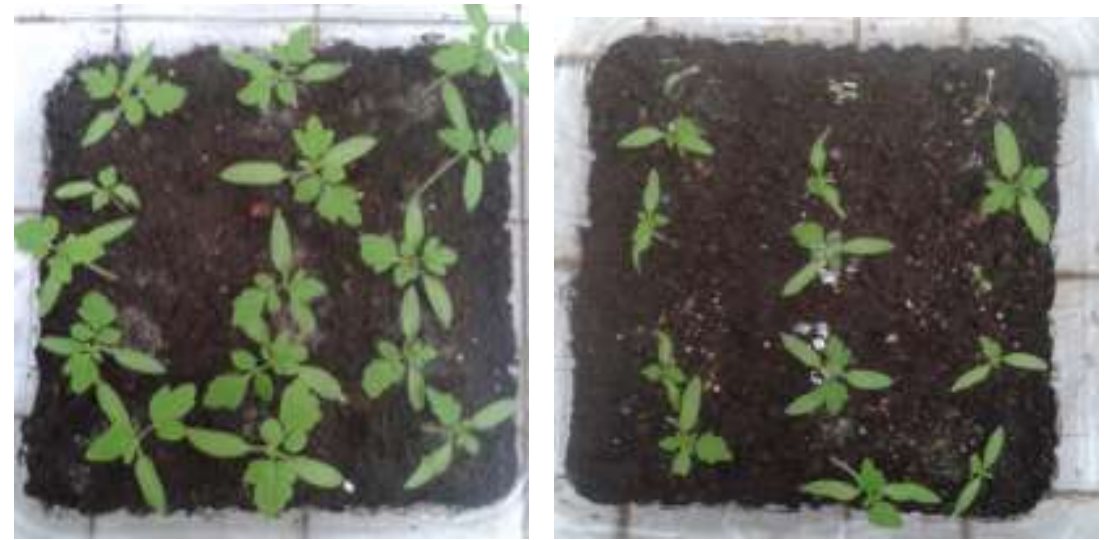

Gambar 1. Pertumbuhan Bibit Cabai 7 Hari Setelah Inokulasi Patogen

A. Perlakuan limbah media jamur Shiitake $(1: 2, \mathrm{v} / \mathrm{v})$; B. Kontrol

\section{KESIMPULAN DAN SARAN}

Ekstrak air limbah jamur Tiram ( $P$. ostreatus) dan Shiitake (L. edodes) dapat menghambat pertumbuhan miselium $R$. solani secara in vitro sebesar $29,1 \%-40,6 \%$. Aplikasi limbah media tanam jamur Tiram dan Shiitake dapat menekan perkembangan penyakit rebah semai pada pembibitan tomat sebesar $57,5 \% \quad-\quad 100 \%$. Persentase penghambatan penyakit sebesar $100 \%$ terdapat pada perlakuan aplikasi limbah jamur Tiram dengan perbandingan 1:2 dan 1:3(v/v).

Perlu dilakukan penelitian lebih lanjut untuk mengetahui mikroorganisme apa saja yang terdapat di dalam limbah media tanam jamur konsumsi (Tiram dan Shiitake) yang bersifat antagonistik terhadap patogen.

\section{UCAPAN TERIMAKASIH}

Limbah jamur Tiram dan Shiitake yang digunakan dalam penelitian ini diambil dari Perusahaan Inti Jamur Raya, Lembang, Bandung
Barat. Oleh karena itu, terimakasih disampaikan kepada Ibu Astrid beserta staf terutama Ibu Hesti yang telah membantu dalam penyediaan limbah jamur konsumsi.

\section{DAFTAR PUSTAKA}

Adedeji K.O \& A.A.O Modupe. 2016. In vitro evaluation of spent mushroom compost on growth of Fusarium oxysporium f. sp lycopersici. Advances in Plants and Agriculture Research 4: 00147. DOI: 10.15406/apar.2016.04.00147 (diakses Juli 2018).

Agrios, G.N. 2005. Plant Pathology $5^{\text {th }}$ Editon. Academic Press. San Diego California.

Ahlawat, O.P \& M.P. Sagar. 2007. Management of Spent Mushroom Substrate. National Research Center for Mushroom (Indian Council of Agricultural Research). Yugantar Prakashan Pvt. Ltd., New Delhi. Tersedia di http://nrcmushroom.org/Bul-SMS.pdf 
Bonanomi, G., V. Antignani, C. Pane, \& F. Scala (2007). Suppression of soil borne fungal diseases with organic amendments. J. Plant Pathol. 89 (3): 311-324

Campbell, L.C \& Madden, V.L. 1990. Introduction Plant Disease Epidemiology. John Wiley and Son, USA. 532 pp.

Dhingra, O.D. \& Sinclair, J.B. 1995. Basic Plant Pathology Methods. Second Edition. Lewis Publishers, Boca Raton.

Goonani Z, K. Sharifi \& H. Riahi. 2011. The effects of spent mushroom compost and municipal solid waste compost on Phytophthora drechsleri in vivo and in vitro. Archives of Phytopathology and Plant Protection. 44,1171-1181.

Istifadah, N. \& C. Nasahi. 2007. Penggunaan bokasi dan kascing untuk menekan penyakit karat (Phakopsora pachyrrizhi Syd.) pada kedelai. Jurnal Agrikultura, 18(1):42-47.

Istifadah, N, J.A. Saleeba, \& P. McGee. 2006. Isolates of endophytic Chaetomium spp. inhibit the fungal pathogen Pyrenophora triticirepentis in vitro. Canadian Journal of Botany, 84:11481155.

Parada RY, S. Murakami, N. Shimomura, \& H. Otani. 2012. Suppression of fungal and bacterial diseases of cucumber plants by using the spent mushroom substrate of Lyophyllum decastes and Pleurotus eryngii. J Phytopathol., 160: 390-396.

Kementerian Pertanian. 2011. Peraturan Menteri Pertanian Nomor 70/Permentan /Sr.140/ 10/2011. Tentang Pupuk Organik, Pupuk Hayati dan Pembenah Tanah. Tersedia on line : http://perundangan.pertanian.go.id /admin/file /Permentan-70-11.pdf
Roy, S., S. Barman, U. Chakraborty, \& B. Chakraborty. 2015. Evaluation of spent mushroom substrate as biofertilizer for growth improvement of Capsicum annuum L. Journal of Applied Biology \& Biotechnology, 3 (03): 022-027

Rinker, D.L. 2005. Recycling Spent Shiitake Substrate. Mushroom Growers' Handbook 2: Chapter 7. Mush World, Seoul. Available at: http://www.alohamedicinals.com/ mushroombook1.zip (Diakses pada Juli 2017)

Semangun, H. 2004. Penyakit - Penyakit Tanaman Hortikultura di Indonesia, Second. Edition. Gadjah Mada University Press, Yogyakarta.

Suess, A. \& J. Curtis. 2006. Report: Value-Added Strategies for Spent Mushroom Substrate in BC. Tersedia di: http://www.al.gov.bc.ca /mushro-om/ guide/value_added_strategies.pdf (Diakses pada Juli 2017)

Palizi, P., E.M. Goltapeh, E. Pourjam, \& N. Safaie. 2009. Potential of oyster mushrooms for the biocontrol of sugar beet nematode (Heterodera schachtii). Plant Protection Research, 49(1): 27-33

Kwak A.M., K.J. Min, S.Y Lee \& H.W. Kang. 2007. Water extract from spent mushroom substrate of Hericium erinaceus suppresses bacterial wilt disease of tomato. Mycobiology 43: 311318.

Istifadah N \& R.P. Sianipar. 2015. Potensi limbah media jamur untuk menekan layu bakteri (Ralstonia solanacearum) pada tanaman kentang. Jurnal Agrikultura, 26, 84-89.

Yusidah, I. \& Istifadah, N. 2018. The abilities of spent mushroom substrate to suppress basal rot disease (Fusarium oxysporum f.sp cepae) in shallot. International Journal of Biosciences, 13 (1):440-448 